\title{
Prevalence of Muscular and Tendinous Variations of Flexor Digitorum Superficialis and Absence of Palmaris Longus Muscle in Turkey: A Population Study
}

\author{
Fatih Irmak $^{1 \oplus}$, Aysin Karasoy Yesilada ${ }^{1 \oplus}$, Selami Serhat Sirvan ${ }^{1 \oplus}$, Kamuran Zeynep Sevim $^{1 \oplus}$
}

\begin{abstract}
:
Prevalence of muscular and tendinous variations of flexor digitorum superficialis and absence of palmaris longus muscle in Turkey: a population study

objective: Studies in different ethnic groups, showed wide variations in terms of the absence of the palmaris longus tendon. The aim of our study is, to document the percentage of the absence of the palmaris longus muscle and flexor digitorum superficialis muscle variations among the Turkish population.

Material and Method: The study group constituted of adult patients who presented to department of Plastic, Reconstructive and Aesthetic Surgery for various reasons, other than a history of hand trauma and chronic illnesses. A total of 533 patients and their relatives (1066 hands) were included in the study. Among 533 people, the ability of isolated flexion of the proximal interphalangeal joint of all fingers (except thumb) and the presence of palmaris longus muscle were investigated with detailed physical examination.

Results: For 533 Turkish individuals ( 272 men and 261 women), aged between 18 and 66 years old, the overall prevalence of absence of palmaris longus muscle was $21.8 \%$ among Turkish population. The overall prevalence of variations of the flexor digitorum superficialis of the fifth digit was $23.7 \%$ in the Turkish population.

Conclusions: In operative techniques, where tendon grafting and tendon transfers are utilized, pre-operative consultation of the patient gains importance since the lack of palmaris longus tendon possibility is determined. Variations and deficiency of fifth digits' flexor digitorum superficialis muscle function can not be proven on clinical examinations, so hand surgeons should be aware about flexor digitorum superficialis muscle variations in preoperative examinations and intraoperative dissections, and try to detect these variations by performing the specific examination tests (independent function, the connection with neighbor digits).

Keywords: Absence of palmaris longus tendon, flexor digitorum superficialis muscle variations, Turkish population
\end{abstract}

ÖZET:

Türkiye'deki Fleksör digitorum süperfisiyalis kas-tendon varyasyonları ve palmaris longus kas-tendon yokluğunun prevalans çalışması

Amaç: Tendon anomalileri nadiren klinik bulgu verir. Bu anomaliler arasında en sık görülenlerinden biri fleksör digitorum süperfisialis tendon varyasyonlarıdır. Değişik etnik gruplarda yapılan çalışmalarda, palmaris longus tendon yokluğunun geniş varyasyonlar gösterdiği sonucuna varılmıştır.

Amaç: Değişik etnik gruplarda yapılan çalışmalarda, palmaris longus tendon yokluğunun geniş varyasyonlar gösterdiği sonucuna varılmıştır. Bu çalışmanın amacı, Türk popülasyonunda palmaris Iongus kasının yokluğu ve fleksör dijitorum süperfisyalis kas varyasyonlarını ortaya koymaktır.

Gereç ve Yöntem: Plastik, Rekonstrüktif ve Estetik Cerrahi kliniğine farklı nedenlerle başvuran, daha önce el travması geçirmemiş, kronik hastalık öyküsü bulunmayan erişkin hasta ve hasta yakınlarından oluşan 533 kişi (1066 el) çalışmaya dahil edildi. Bireylerde tüm parmaklarda proksimal interfalangeal eklemin izole fleksiyon yapabilmesi ve palmaris longus tendon mevcudiyeti ayrıntılı fizik muayene ile araştıııımıştır.

Bulgular: Olguların yaşı 18-66 arasında değişmekteydi. Ortalama yaş: 33.6 olarak bulundu. 533 olgunun 272 'si erkek, 261'i kadın olarak saptandı. Tüm popülasyonda palmaris longus tendon yokluğu oranı \%21.8 olarak bulundu. Kadınlarda palmaris longus tendon yokluğunun erkeklerden daha sık olduğu gözlenmiştir. Tüm popülasyonda 5. parmakta izole proksimal interfalangeal eklemde fleksiyon hareketi olmayanların oranı $\% 23.7$ olarak saptandı.

Sonuç: Yaşları 18 ile 66 arasında değişen 533 Türk bireyde (272 erkek, 261 kadın), palmaris longus kasının yokluğunun toplam görülme oranı \%21.8 idi. Beşinci parmağa ait fleksör dijitorum süperfisyalis varyasyonları toplam sıklığı ise Türk popülasyonu içerisinde \%23.7 idi.

Tartışma: Tendon grefti ya da tendon transferleriyle onarım planlanan olgularda palmaris longus tendon eksikliği olasılığı her zaman akılda olmalıdır, bu da preoperatif muayenenin ne kadar önemli olduğunu gösterir. Fleksör digitorum süperfisialis tendon yokluğu klinik olarak yapılan muayenelerle saptanamayabilir, bu yüzden el cerrahları gerek operasyonda gerekse operasyon öncesi muayene esnasında eldeki fleksör digitorum süperfisialis varyasyonlarını çok iyi bilmeli, özel muayene testlerini uygulayarak olası fleksör digitorum süperfisialis anomalilerini saptamaya çalışmalıdır (bağımsız fonksiyon, komşu parmaklarla bağlantı). Anahtar kelimeler: Palmaris longus tendon yokluğu, fleksör digitorum süperfisiyalis kas varyasyonları, Türk populasyonu

Ş.E.E.A.H. Tıp Bülteni 2017;51(4):303-8
This study was presented as Oral Presentation at the $33^{\text {rd }}$ National Turkish Plastic, Reconstructive and Aesthetic Surgery Congress on September 14-18, 2011.

${ }^{1}$ Health Sciences University, Sisli Hamidiye Etfal Application and Research Center, Department of Plastic, Reconstructive and Aesthetic Surgery, Istanbul - Turkey

Yazışma Adresi / Address reprint requests to: Fatih Irmak,

Health Sciences University, Sisli Hamidiye Etfal Application and Research Center, Department of Plastic, Reconstructive and Aesthetic Surgery, Istanbul - Turkey

E-posta / E-mail:

dr.fatihirmak@gmail.com

Geliş tarihi / Date of receipt:

7 Haziran 2017 / June 7, 2017

Kabul tarihi / Date of acceptance: 25 Temmuz 2017 / July 25, 2017 


\section{INTRODUCTION}

The prevalence of the absence of palmaris longus $(\mathrm{PL})$ tendon has been extensively studied, since first described by Colombos in De Re Anatomica Libri in 1559 (1).

It is well known that in different ethnic groups, the absence of PL tendon prevalence shows wide variation. Another tendon which shows common variation is the flexor digitorum superficialis (FDS) tendon. According to results of Ohtani's (2) anatomical studies, FDS tendon variations range between $0-20 \%$; these variations are FDS muscle belly anomaly, musculotendineous unit connection abnormalities and the total absence of the fifth digits' FDS tendon. FDS tendon variations can be considered as tendon injury in patients with hand injury. The standard technique for examination and determination of FDS function was described by Kaplan (3). According to Kaplan, during investigation of relevant finger flexion, other fingers should be kept in full extension by grabbing the tip of finger, so contribution of flexor digitorum profundus (FDP) to flexion can be eliminated and isolated FDS function can be assessed (Figure-1).

Palmaris longus muscle starts from the medial epicondyle and passes over the anterior transverse ligament as a long and thin tendinous structure and ends in the palmar aponeurosis (4). Palmaris longus tendon can be used in various reconstructive procedures with other tendons, such as the plantaris tendon, extensor digiti minimi tendon and extensor indicis proprius tendon. PL tendon is mainly used as the donor tendon in tendon transfers and tendon grafting procedures, lip augmentation, eyelid ptosis surgery and correction of facial paralysis (5).

The aim of this study is determine the prevalence of absence of the PL tendon (as unilateral or bilateral) and the prevalence of FDS tendon variations in Turkish population.

\section{MATERIALS AND METHODS}

The study was approved by Clinical Ethics Committee (decision number:35, decision date: 24/05/2011) and informed consent was obtained from all patients. A total of 533 randomly selected adult patients (272 men and 261 women-1066 hands) who were admitted to the Department of Plastic, Reconstructive and Aesthetic Surgery, were examined for the absence of PL tendon and variations of FDS tendon between January to September 2011.

Patients with a history of chronic diseases such as diabetes and ischemic heart disease, history of previous hand injuries and previous hand surgery for any reason were excluded from the study (Table- 1 ).

\section{Table-1: Exclusion criteria of study}

\begin{tabular}{l}
\hline Exclusion criteria \\
\hline - Younger than 18 years of age \\
previous surgery and trauma \\
- Congenital hand anomalies \\
- Tendinitis \\
- Connective tissue diseases, rheumatoid arthritis \\
- Cocking and catching in finger and hand movements \\
- Previous tendon injury or tendon operations
\end{tabular}
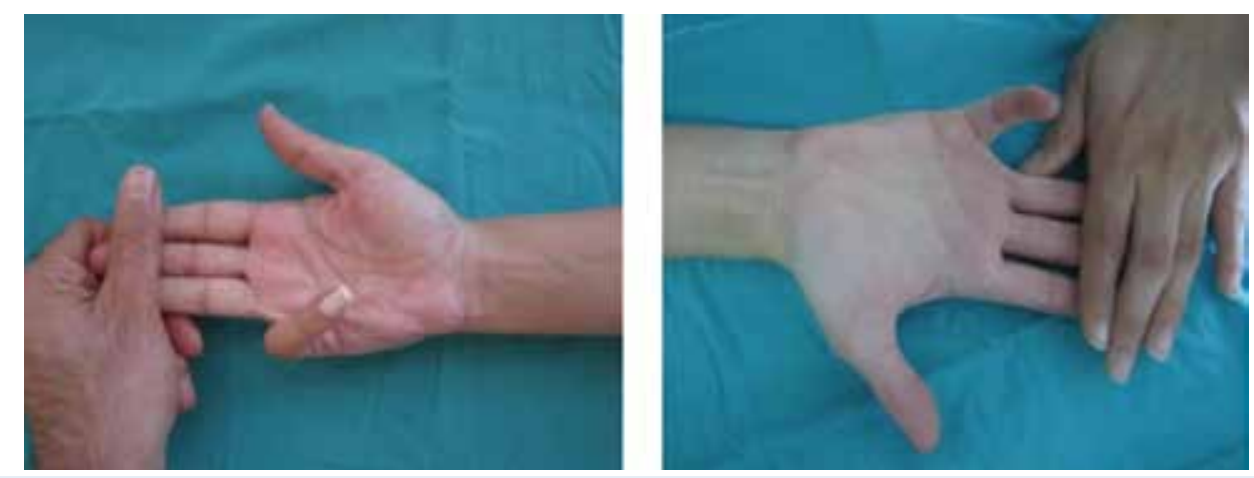

Figure-1: Kaplan's FDS function inspection. a. Fifth digit's independent flexion during other fingers in full extension. b. Absence of fifth digit active and isolated PIP joint flexion 
Individuals who were over 18 years old were included in the study.

All patients were investigated for the fifth digits' proximal interphalangeal (PIP) joint flexion status and the prevalence of PL tendon absence (according to Schaeffer's test (6), Thompson's test (7), Mishra's test (8), Pushpakumar's tests (9)) (Figure-2).

Gender distribution among 533 adult patients were as follows: 272 male and 261 female. The age ranged between 18-66 years, and the mean age was 33.6 years old. Of the patients, 249 were righthanded (93.4\%) and 17 patients were left-handed (6.6\%).

All examinations were performed by 2 different hand surgeons.

In order to examine the isolated FDS function, while relevant finger was in relaxed position, other finger's interphalangeal and metacarpophalangeal joints should be in full extension position. During this position; the FDS tendons' PIP joint flexion becomes independent from FDP tendon. In the meantime, if there is only distal interphalangeal joint flexion is observed, this means that there is no isolated FDS flexion (Figure-1). If the patient could not perform the isolated fifth digit FDS tendon function, then we tested for the function of fourth digits' FDS tendon. If both fourth and fifth digits couldn't perform FDS tendon functions, then we investigated about second and third digits' FDS tendon function.

In all patients, the presence of PL tendon was tested by Schaeffer's test, Thompson's test, Mishra's test, Pushpakumar's tests (Figure-2). If any one of these tests proves the existence of PL tendon, even if PL tendon wasn't detected by other tests, we accept that the PL tendon is present. However, in order to decide if the PL tendon is absent, the tendon needs to be non-palpable and non-visible in all of the above tests.

All statistical analysis was performed by using the SPSS program (Statistical Package for Social Sciences
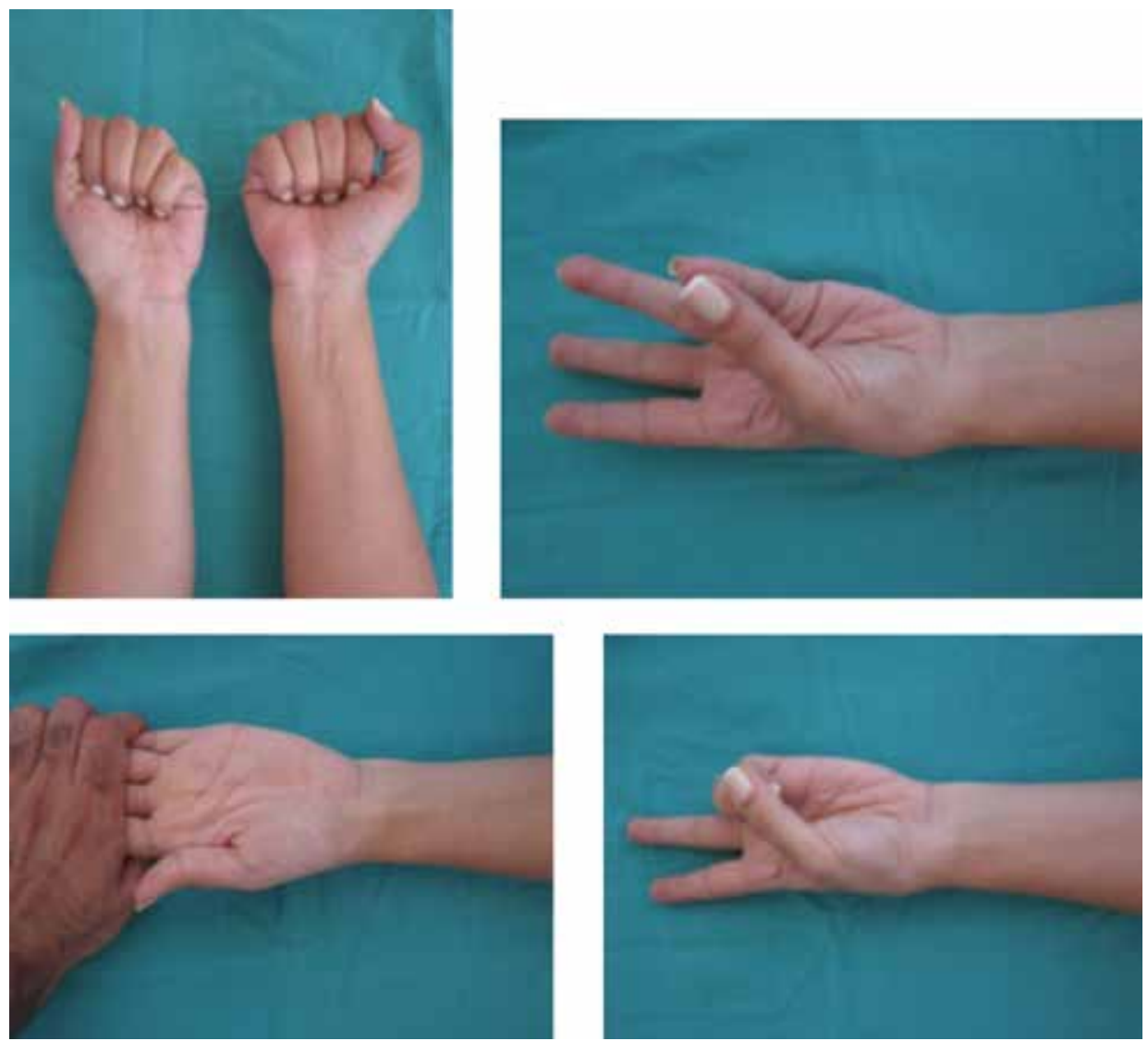

Figure-2: PL examination tests. a. Thompson's test. b. Schaeffer's test. c. Mishra's test. d. Pushpakumar's test. Searching for PL tendon presence 
for Windows 7.0). In addition, the chi-square analysis was performed to compare palmaris longus absence / flexor digitorum superficialis tendon anomaly and $\mathrm{p}<0.05$ was considered statistically significant.

\section{RESULTS}

In 498 patients, the right hand was dominant $(93.4 \%)$ and in 17 patients the left hand was dominant (6.6\%). The absence rate of the PL tendon was found as $21.8 \%$. In women $(22.3 \%)$, the rate of absence of $\mathrm{PL}$ tendon was found to be more frequent than men (21.3\%).

Bilateral absence of the PL tendon (82 patients $15.4 \%$ ), was seen more frequently than unilateral absence of the PL tendon (34 patients - 6.3\%) (Table-2).

The rate of absence of active and isolated movement of thefifth fingers' proximal interphalangeal
(PIP) joint function were $23.7 \%$. Absence of the isolated and active flexion of fourth and fifth fingers' PIP joint were seen as $11.8 \%$, while the absence of the PIP joint flexion of the third, fourth and fifth fingers were $1 \%$. As a result, only the absence of active and isolated fifth finger DIP joint flexion were $10.9 \%$.

FDS tendon movement disorder of fifth digit was seen more often in women $(24.6 \%)$ than men (22.7\%). Similar to the incidence of absence of PL tendon; deficiency of bilateral active isolated PIP joint flexion of fifth digit (78 individuals, $14.7 \%$ ) was higher than unilateral deficiency (48 individuals 9\%) (Table-3).

For the absence of PL tendon, there was no statistically significant difference between men and women ( $p>0.05)$. Bilateral absence of the PL tendon was significantly higher than unilateral absence of the PL tendon $(\mathrm{p}<0.05)$. Isolated and active fifth

Table-2: Right and left hands (unilateral) and bilateral absence of the PL tendon, evaluated according to gender

\begin{tabular}{lcccc}
\hline & Right & Left & Bilateral & Total \\
\hline Male (n: 272) & $8(2.9 \%)$ & $8(2.9 \%)$ & $42(15.4 \%)$ & $58(21.2 \%)$ \\
Female (n: 261) & $14(5.4 \%)$ & $4(1.5 \%)$ & $40(15.4 \%)$ & $58(22.3 \%)$ \\
Total (n: 533) & $22(4.1 \%)$ & $12(2.2 \%)$ & $82(15.4 \%)$ & $116(21.8 \%)$
\end{tabular}

Table-3: Active and isolated fifth finger PIP joint function distribution according to gender

\begin{tabular}{lcccc}
\hline & Right & Left & Bilateral & Total \\
\hline Male (n: 272) & $16(5.8 \%)$ & $6(2.2 \%)$ & $40(14.7 \%)$ & $62(22.7 \%)$ \\
Female (n: 261) & $14(5.3 \%)$ & $12(4.6 \%)$ & $38(14.6 \%)$ & $64(24.5 \%)$ \\
Total (n: 533) & $30(5.7 \%)$ & $18(3.3 \%)$ & $78(14.7 \%)$ & $126(23.7 \%)$
\end{tabular}
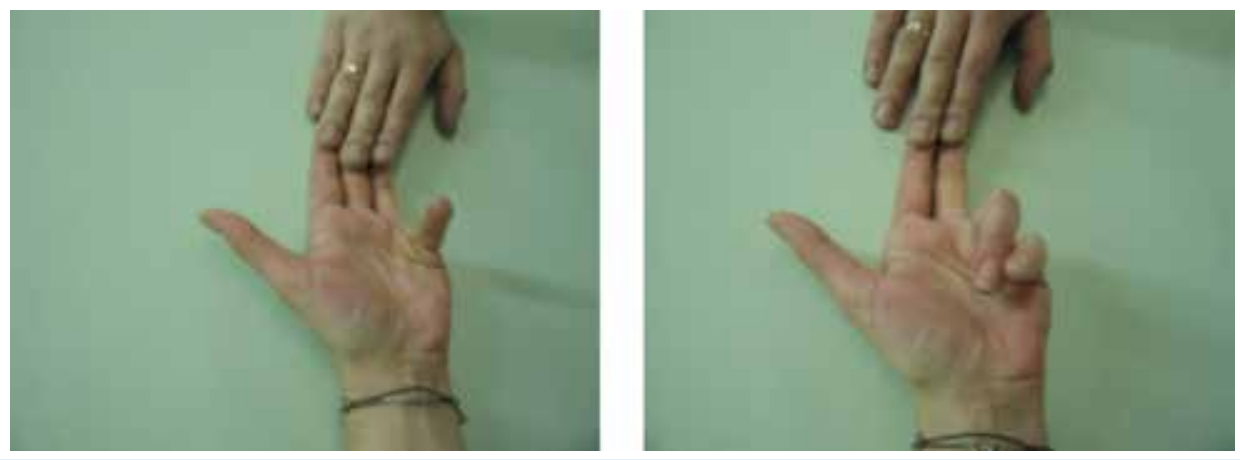

Figure-3: a. While other fingers are in full extension, related fingers' PIP joint can't make flexion. b. In the same patient while second and third fingers are in extension position, fourth and fifth fingers' PIP joint can make flexion. So, this position variation shows that in this case fourth and fifth fingers' FDS tendons are interconnected 
fingers' FDS function anomaly was significantly higher in women than in men $(p<0.05)$. Bilateral absence of the active and isolated FDS function was found significantly higher than the absence of unilateral FDS tendon function $(p<0.05)$.

\section{DISCUSSION}

Flexor digitorum superficialis tendon abnormalities can be categorized as muscle and tendon abnormalities. Muscle anomalies may present as a palmar mass or carpal tunnel symptoms, and can be classified as three different types;

1. Short type; arising fom carpal ligament and muscle.

2. Long PL muscle; extending to carpal tunnel.

3. Additional muscle with digastric muscle, continuing as a tendon in the palmar area.

Anomalies of the tendons are rarely present with clinical symptoms. Among tendon anomalies, FDS function variations are seen most frequently. Earlier, the identification of short type variation of second digit's FDS and short type of fifth digits' FDS variation were defined as the similar variations (10). These observations support the hypothesis of second digits' FDS and fifth digits' FDS originating from the palmar area and then migrating to forearm. When the FDS muscle doesn't migrate to the forearm area, and remain in its original place, a short variation of FDS muscle forms (11). Fifth digits' FDS tendon usually moves together with the second digits' FDS tendon, while some authors reported that fifth and second digits' FDS tendons have been associated with each other. Therefore, this close relationship between the tendons, cause injury to second or fifth digits' FDS tendon, and the neighboring finger can become involved with some malformations (12).

In the literature, absence of fifth digits' FDS tendon function is not consistent and, is reported to be between $0-20 \%$ (3). The reason for this wide range in literature is due to different populations having different anatomical features and physical examination methods that may not be sufficient or incorrect to interpret the analysis of anatomical variations. Anatomical lack of the tendon or absence of isolated function of FDS are caused by aberrant connections or variations.

According to a research among the Chinese population, this rate was $6.4 \%$, and according to a Japanese cadaveric study, absence of fifth digits' FDS tendon was $2 \%(1,2)$.

According to an other cadaveric study conducted on 68 cadaver hands; a connection was found between second and fifth digits' FDS tendon in 21 hands, a connection between fourth and fifth digits' FDS tendon in 23 hands; in 3 hands, there was a connection between third, fourth and fifth digits', and in other 3 hands, a connection was found between second, fourth and fifth digits', a connection between second, third, fourth and fifth digits' FDS tendon in 2 hands, and surprisingly in 2 hands, fifth digits' FDS tendons were originating from palmaris longus tendon (3).

According to our study, absence of function of the fifth digits' FDS tendon (proximal interfalangeal joint movement) was $23.7 \%$. Absence of both fourth and fifth digits' PIP joint's active and isolated movement was $11.8 \%$, absence of thirth, fourth and fifth digits' PIP joint movement was $1 \%$. In the latter group, if the extension of second finger has been eliminated, all of the fingers could make PIP joint flexion. As a result, absence of fifth digits' active and isolated movement in PIP joint was 10.9\% (Figure-3).

According to other studies, absence of PL tendon was higher in the left hand and in women, bilateral PL tendon absence was higher than unilateral tendon absence (13-15). According to Kose et al. (16), absence of $\mathrm{PL}$ tendon prevalence in the Turkish population was $26.6 \%$, and according to other previous studies, this rate was $63.9 \%$ (17). This study showed the highest rate of PL tendon absence in all of the studies. Lowest rate of PL tendon absence prevalence in literature was in Uganda population and the rate was $1.02 \%$ (18).

According to our study the prevalence of absence of PL tendon rate was $21.8 \%$ in Turkish population. PL tendon absence in women (22.3\%) were higher than in men $(21.3 \%)$. The rate of bilateral PL tendon absence (82 individuals, $15.4 \%$ ) was higher than unilateral PL tendon absence (34 individuals, 6.3\%).

Inspection methods for detection of the absence of the PL tendons are; Schaeffer's test (6), Thompson's 
test (7), Mishra's test (8), Pushpakumar's tests (9).

In Thompson's test, the person is asked to make a firm fist with both hands. But at this time, as the flexor carpi radialis (FCR) tendon can be visible over the wrist, so PL tendon may be confused with the FCR tendon, and this presents the weak point of this test.

In the Schaeffer's test, the wrist should be in a slightly flexed position, the thumb and the fifth digit should be in the opposite position.

In Mishra's test PL tendon examination is performed by making a rigid first finger abduction.

Pushpakumar's test is the making 2-finger sign, second and thirth fingers are in full extension while other fingers and wrist in flexion, thumb in opposition and flexion position (1) (Figure-2).

The disadvantage of the various examination tests for detecting the PL tendon presence (Schaeffer's test, Thompson's test, Mishra's test ve Pushpakumar's test) is that the prominence of PL can be confused with flexor carpi radialis tendon prominence. Another disadvantage of these tests is that they require palmar abduction, therefore, in median palsy patients, results of the tests are not reliable (1).

In one case, preoperative examination of patient showed absence of isolated flexion in the 4 fingers' (except thumb) PIP joint, who had a traumatic injury of forearm. The patient had fourth finger FDS tendon laceration, and in operative dissection it was observed that all of FDS muscles were bundled together, resulting in one muscle mass, and the patient making en-bloc flexion of 4 finger in PIP joint (19). In traumatic patients if there are functional problems, anatomic variations should be kept in mind.

In conclusion, absence of fifth digits' FDS tendon can not be proven on clinical examinations, so hand surgeons should be aware about FDS variations in preoperative examinations and intraoperative dissections (20).

Preoperative examination for presence of PL is utmost important prior to tendon transfers and tendon grafting procedures, and PL tendon agenesis should be kept in mind.

\section{REFERENCES}

1. Sebastin SJ, Lim AY. Clinical assessment of Absence of the palmaris longus and its association with other anatomical anomalies -a Chinese population study. Ann Acad Med Singapore 2006; 35: 249-53.

2. Ohtani O. Structure of the flexor digitorum superficialis. Okajimas Folia Anat Jpn 1979; 56: 277-88. [CrossRef]

3. Kaplan EB. Muscular and tendinous variations of the flexor superficialis of the fifth finger of hand. Bull Hosp Joint Dis 1969; 30: 59-67.

4. Kaplan EB. Spinner M. Important musculer variations of the hand and forearm. In: Spinner $M$, editor. Kaplan's functional and surgical anatomy of the hand. 3rd ed. Philadelphia: Lippincott Williams \& Wilkins; 1984. p 335-7.

5. Thompson NW. Mockford BJ, Cran GW. Absence of palmaris longus muscle: a population study. Ulster Med J 2001; 70: 22-4.

6. Schaeffer JP. On the variations of the palmaris longus muscle. Anat Rec 1909; 3: 275-8.

7. Thompson JW, McBatts J, Danforth $\mathrm{CH}$. Hereditary and racial variations in the musculus palmaris longus. Am J Phys Anthrop 1921; 4: 205-20. [CrossRef]

8. Mishra S. Alternative tests in demonstrating the presence of palmaris longus. Indian J Plast Surg 2001; 34: 12.

9. Pushpakumar SB, Hanson RP, Carroll $S$. The 'two finger' sign: Clinical examination of palmaris longus $(P L)$ tendon. Br J Plast Surg 2004;57:184-5. [CrossRef]

10. Wesser DR, Calostypis F, Hoffman S. The evolutionary significance of an aberrant flexor superficialis muscle in the human palm. J Bone Joint Surg 1969; 51A: 396-8. [CrossRef]

11. Kobayashi N, Saito S, Wakisaka H, Matsuda. Anomalous flexor of the Little Finger. Clinical Anatomy 2003; 16: 40-3. [CrossRef]

12. Yilmaz A, Bozer C, Ulucam E, Taskinalp O. An anomaly of flexor muscles of the fifth (little) finger of the hand: An anatomical Case Report. Clinics (Sao Paulo) 2009; 64: 1133-5.

13. Thompson JW, McBatts J, Danforth $\mathrm{CH}$. Hereditary and racial variations in the musculus palmaris longus. Am J Phys Anthrop 1921; 4: 205-20. [CrossRef]

14. Reimann AF, Daseler EH, Anson BJ, Beaton LE. The palmaris longus muscle and tendon; a study of 1600 extremities. Anat Rec 1944; 89: 495-505. [CrossRef]

15. Machado AB, DiDio LJ.Frequency of the musculus palmaris longus studied in vivo in some Amazon indias. Am J Phys Anthrop 1967; 27: 11-20. [CrossRef]

16. Kose O, Adanir O, Cirpar M, Kurklu M, Komurcu M. The prevalance of absence of the palmaris longus: a study in Turkish population. Arch Orthop Trauma Surg 2009; 129: 609-11. [CrossRef]

17. Ceyhan O, Mavt A. Distrubition of agenesis of palmaris longus muscle in 12 to 18 years old age groups. Indian J Med Sci 1997; 51: 156-60.

18. Mbaka GO, Ejiwunmi AB. Prevalence of palmaris longus absence-a study in the Yoruba population. Ulster Med J 2009; 78: 90-93.

19. Yesilada AK, Tatlıdede HS, Cakmak E, Kıyak MV, Kılınç L. Anomalous large unique muscle belly of flexor digitorum superficialis and the absence of palmaris longus in the forearm. J Plast Reconstr Aesthet Surg 2013; 66: 137-9. [CrossRef]

20. Tan JS, Oh L, Louis DS. Variations of the flexor digitorum superficialis as determined by an expanded clinical examination. J Hand Surg Am 2009; 34: 900-6. [CrossRef] 